\title{
11
}

\section{Environmental Modeling of a Claypan Watershed using HSPF}

\author{
Menghua Wang, J. Obiukwu Duru, Allen T. Hjelmfelt, Jr., Fessehaie \\ Ghidey and Allen Thompson
}

The Hydrological Simulation Program - FORTRAN (HSPF) is a comprehensive, continuous model designed to simulate watershed hydrology and water quality. Its performance in simulating surface runoff, sediment, and pesticide loss from Goodwater Creek, a $72.8 \mathrm{~km}^{2}\left(28 \mathrm{mi}^{2}\right)$ USDA agricultural research watershed, was evaluated. The watershed is located in Central Missouri in the Central Claypan Major Land Resource Area (MLRA 113) and has a nearly level to gently sloping surface. The low permeability of the claypan layer coupled with the nearly level slope causes unique hydrologic problems. In this evaluation, most of the model parameters related to hydrology, sediment, and pesticide transport were carefully selected from previous studies. Some of the model parameters were directly calculated and others were calibrated, based on the detailed field data on hydrology, water quality, and field operations - such as cultivation and chemical application - from a 36 ha $(89 \mathrm{ac})$ research field within the Goodwater Creek watershed. For accurately simulating watershed responses, field activities were considered by using the SPEC-ACTION block in HSPF. The calibration revealed that some model parameters, most notably infiltration index, take numerical values outside recommended ranges in order to define the claypan watershed behavior accurately. With a proper calibration, however, the HSPF model simulated runoff, sediment yield, and chemical loss from the Goodwater Creek watershed well.

\footnotetext{
Wang, M., J. Duru, A.T. Hjelmfelt, F. Ghidey and A. Thompson. 2000. "Environmental Modeling of a Claypan Watershed using HSPF." Journal of Water Management Modeling R206-11. doi: 10.14796/JWMM.R206-11.

(C) CHI 2000 www.chijournal.org ISSN: 2292-6062 (Formerly in Applied Modeling of Urban Water Systems. ISBN: 0-9683681-3-1)
} 


\subsection{Introduction}

HSPF is the most comprehensive package for simulation of watershed hydrologic and associated water quality processes, on pervious and impervious land surfaces, in the soil profile and in streams and well-mixed impoundments (Donigian et al., 1984). It has been used for agricultural watershed simulations and best management practice (BMP) evaluations. Srinivasan et al. (1998) applied HSPF to two glaciated watersheds, Purdy Creek $\left(22.95 \mathrm{~km}^{2} / 8.9 \mathrm{mi}^{2}\right)$ and Ariel Creek $\left(39.44 \mathrm{~km}^{2} / 15.3 \mathrm{mi}^{2}\right)$, in northeastern Pennsylvania for hydrology simulation. Both watersheds have wetlands, over $50 \%$ of forests, and poorly drained soils due to low hydraulic conductivity and presence of fragipans. Laroche et al. (1996) used HSPF to simulate hydrology and pesticide transport from a 78 ha $(192 \mathrm{ac})$ watershed in the province of Quebec, Canada. Predominant soil types in this watershed vary in texture from sandy silt on gravel to fine silty sand. Moore et al. (1988) and Chew et al. (1991) applied HSPF to two west Tennessee agricultural watersheds for simulating sediment, nitrogen, and atrazine, and for BMP studies. The primary soil type in the two small west Tennessee watersheds is silt loam. Donigian et al. (1983) applied HSPF to Four Mile Creek, a $52 \mathrm{~km}^{2}\left(20 \mathrm{mi}^{2}\right)$ agricultural watershed located in central lowa, to simulate transport of sediment, nutrients, and pesticides. To demonstrate the application of HSPF on large scale basins, Donigian et al. (1984) transferred the Four Mile Creek simulation to the Iowa River basin $\left(7240 \mathrm{~km}^{2} / 2802 \mathrm{mi}^{2}\right)$ simulation. Watershed modeling of agrichemicals in the Walnut Creek watershed in Iowa is another example of their HSPF studies (Donigian et al. 1995).

HSPF has not been widely used in the Central Claypan Major Land Resource Area (MLRA) 113. This MLRA covers a $28,570 \mathrm{~km}^{2}\left(11,056 \mathrm{mi}^{2}\right)$ area with about $60 \%$ of cropland. Corn, soybeans, other feed grains, and hay for cattle and other livestock are the main crops. The area is characterized by a nearly level to gently sloping surface underlaid by a claypan (SCS 1981). The objective of this study is to use research data from the Goodwater Creek to evaluate HSPF for claypan soil watershed simulation.

The Goodwater Creek watershed, with a drainage area of $72.8 \mathrm{~km}^{2}\left(28 \mathrm{mi}^{2}\right)$, was established as a research catchment by the U.S. Department of Agriculture, Agricultural Research Service, in 1971. The agricultural watershed, located in central Missouri and in the Central Claypan MLRA 113. Because of the low permeability of the claypan soil, surface runoff in the watershed represents nearly $40 \%$ of the mean annual precipitation.

The watershed has been used for various hydrology and water quality studies. Previous studies indicated that the concentrations of pesticides and nutrients in Goodwater Creek could be much higher than their respective maximum concentration levels (MCLs) if surface runoff occurs within six weeks of application. Contamination of surface water with pesticides is a major public 
concern for water quality in Missouri and the Midwest (Alberts et al., 1995; Hjelmelt et al., 1995).

The watershed has been monitored for hydrologic studies by the USDA Agricultural Research Service since 1971. Several models have been applied to the watershed in an attempt to generalize the hydrologic observations. Success has been limited because of wetness problems during the rainy season, caused by the low permeability of the claypan layer coupled with the nearly level slope (L. Kramer personal communication 1978). Wang and Hjelmfelt (1998) developed a DEM (digital elevation model)-based watershed model, and applied this to the watershed. This model is good for single event simulations, but not for long-term simulations.

For intensive water quality studies, streamflows in the Goodwater Creek and the outflows from three research fields within the watershed have been sampled for water quality analyses since 1990 . The three fields were established for investigating the impact of different farming systems on water quality. Detailed field activity data with corresponding water quality results have been recorded and used for water quality studies (Hjelmfelt and Wang, 1998; Ghidey et al., 1997). This wealth of field data and experience from previous studies provided major benefits for this HSPF evaluation.

\subsection{Data Preparation}

In this study, the HSPF model calibration was mainly conducted on a 36 ha (89ac) field within the Goodwater Creek Watershed. The cropland field is represented as a pervious land segment in HSPF. The model verification for hydrology calibration was conducted on the whole watershed with the drainage area of $72.8 \mathrm{~km}^{2}$. The watershed was divided into 32 land segments, each assumed to produce a homogeneous hydrologic and water quality response and to have a reach inside. Overland flows from each land segment converge into the reach inside and are routed into the next reach downstream. The watershed segmentation and topographic measurements, such as sub-watershed area, overland flow length and slope, and main stream channel length and slope, were conducted using geographic information system (GIS) (Qiu, 1996). The relations between water heads and discharges, termed as FTABLES in the HSPF model, for the reaches in Goodwater Creek were measured and others were calculated based on Manning's equation. For open channel flow, the equation is expressed as:

where:

$$
Q=A \frac{\xi}{n} R^{2 / 3} \sqrt{S_{o}}
$$

$$
\mathrm{Q}=\text { the flow rate }\left(\mathrm{L}^{3} / \mathrm{T}\right)
$$




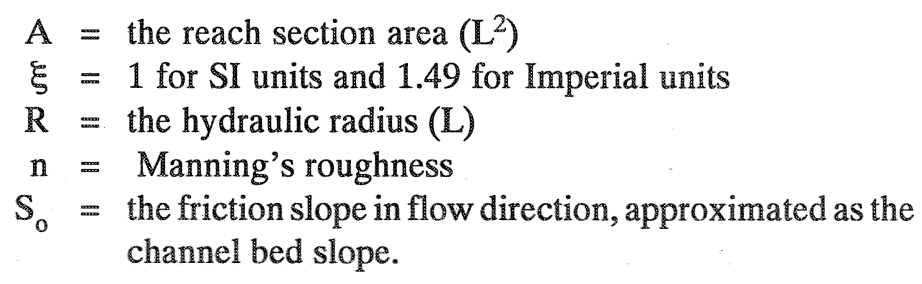

For simulating hydrology and snow melt, daily data of precipitation, evaporation, air temperature, wind speed, dew point temperature, and solar radiation from site rain gages and a nearby weather station were used in this study. The daily data of runoff from the outlets of the research field and the whole watershed were used for hydrology calibration and verification. To evaluate the performance of HSPF for simulating sediment and atrazine daily losses, three years (1993-1995) of observed records of pollutant concentrations in the outflows from the research field were used. Field cultivation and agricultural chemical applications, which contribute to significant soil erosion and chemical contamination problems, were considered in this evaluation. Table 11.1 presents cropping and atrazine application information for the field. Field cultivation was conducted before planting.

Table 11.1. Crop planting and atrazine applications in the three years of 1993-1995.

\begin{tabular}{cllll} 
Year & Crop & Planting Date & \multicolumn{2}{c}{ Atrazine Application } \\
\hline & & & Date & Rate (kg/ha) \\
1993 & Corn & $05 / 15 / 93$ & $05 / 14 / 93$ & 2.24 \\
1994 & Soybean & $05 / 21 / 94$ & - & 0 \\
1995 & Corn & $06 / 15 / 95$ & $06 / 15 / 95$ & 1.94 \\
\hline
\end{tabular}

\subsection{HSPF Simulation}

\subsubsection{Hydrology Calibration and Verification}

The objective of this study is to model pesticides and sediment contaminants of Goodwater Creek. However, the hydrologic process provides the transport vehicle for all the pollutants. Therefore, a successful simulation of the watershed hydrology through careful and accurate parameter calibration constitutes an essential first step in the modeling of the pollutants. The model was first calibrated on a 36 ha $(89 \mathrm{ac})$ research field within the Goodwater Creek watershed. The field is a cropland that was represented by a pervious land in the 
HSPF model. The calibration used three years (1993-1995) of observed records of precipitation, runoff, and other climatic data. Because of climatic similarities between Iowa and Missouri, estimation of initial parameter values for hydrologic simulation was derived from the Iowa River study in the application guide for HSPF (Donigian et al., 1984). Our estimation also relied on the guidelines provided by Donigian and Davis (1978). Selected initial values, however, resulted in an unrealistic large portion of groundwater, about $50 \%$ of the total runoff. Hjelmfelt et al. (1999) reported that surface runoff represents $85 \%$ of the total streamflow in the Goodwater Creek watershed because of an underlying claypan.

To obtain the best simulation of stream flow, the values of the parameters related to groundwater movement were adjusted to nearly zero because of the claypan, and the parameter of infiltration index, INFLIT, was adjusted from $0.0254 \mathrm{~cm} / \mathrm{hr}(0.01 \mathrm{in} . / \mathrm{hr})$ to $0.00254 \mathrm{~cm} / \mathrm{hr}(0.001 \mathrm{in} . / \mathrm{hr})$. Our final adjustment made the simulated total streamflow strikingly close to the observed, $118.31 \mathrm{~cm}$ versus $114.33 \mathrm{~cm}$ ( $46.57 \mathrm{in}$. versus $45.01 \mathrm{in}$.), and the simulated surface runoff averages $82 \%$ of the total streamflow. After the field calibration, the model was applied to the entire Goodwater Creek watershed. Hydrology of Goodwater Creek watershed for eleven continuous years (1985-1995) was simulated. HSPF simulated the total annual runoff as $353.52 \mathrm{~cm}$ (139.18 in.). The observed total runoff in the eleven years is $363.78 \mathrm{~cm}$ (143.22 in.). The difference between the simulated and observed is $2.82 \%$. The model tended to slightly underpredict high peaks and overpredict low peaks. The overprediction/underprediction was, however, relatively minor. It was concluded that HSPF simulated the hydrology of the Goodwater Creek, a claypan watershed, with good accuracy.

\subsubsection{Sediment Simulation}

Pesticide and nutrients are transported from the watershed either in solution with runoff or with eroded sediment particles. Therefore, accurate simulation of hydrology and sediment processes is a necessary requirement for a successful chemical simulation. HSPF for simulating farmland soil erosion and transport with overland flows was calibrated on the research field, which was also used for the runoff calibration. The calibration used two years (1993 and 1995) of observed sediment records and field cultivation data. Field cultivation activities were considered by resetting the storage of detached sediment (DETS) using the SPEC-ACTION block in HSPF (A. S. Donigian personal communication 1998). Major model parameters for sediment simulation are KRER and JRER, the coefficient and exponent in the soil detachment equation, KSER and JSER, the coefficient and exponent in the detached sediment washoff equation, SMPF, the supporting management factor, AFFIX, the soil compaction rate, and COVER, the fraction of land surface which is shielded from rainfall detachment. Their 
initial values were derived from various literature sources (Donigian et al., 1984; Chew et al., 1991; Moore et al., 1988; Elliot and Ward, 1995). To get a better fit between observed and simulated sediment loss, several parameters were adjusted. KRER was adjusted from 0.43 to 0.30 , JRER from 2.0 to 2.2, AFFIX from 0.03 to 0.05 , KSER from 1.8 to 1.5 , JSER from 2.0 to 1.6 , and DETS for field cultivation from $4.48 \mathrm{t} / \mathrm{ha}$ to $5.39 \mathrm{t} / \mathrm{ha}$. The final total simulated sediment loss in the two years of 1993 and 1995 is $5.39 \mathrm{t} / \mathrm{ha}$, close to the observed $5.94 \mathrm{t} / \mathrm{ha}$. The simulated and observed sediment losses in the cultivation period from May to July are 4.31 and $4.67 \mathrm{t} / \mathrm{ha}$, respectively. These total simulated and observed values in the two years match well. The sediment loss is overpredicted in 1993 and underpredicted in 1995. In general, however, the sediment results are acceptable.

\subsubsection{Chemical Simulation}

Atrazine contamination of streams and surface water impoundments is one of the most important water quality problems in the Midwest. The HSPF model for simulating atrazine transport with runoff and sediment was calibrated on the same research field used for runoff and sediment simulation. The calibration used three years (1993-1995) of measured herbicide concentration data from the 36 ha field outflows, as well as herbicide application dates and rates (Table11.1). HSPF provided the SPEC-ACTION block to define these application data. The major atrazine parameters for HSPF simulation are: CMAX, the maximum solubility of the herbicide in water; $\mathrm{K}_{1}$ and $\mathrm{N}_{1}$, the coefficient and exponent parameters for the single-value Freundlich isotherm equation; and herbicide degradation rates in the surface, upper, and lower soil layers, and groundwater (SDGCON, UDGCON, LDGCON, ADGCON). In the model calibration, a CMAX value of $33 \mathrm{ppm}$ was used (Wauchope et al., 1992). This value was also used for atrazine by Moore et al. (1988), Donigian et al. (1995), and Laroche et al. (1996). Atrazine's measured half-life in the soil surface was twelve days at the site (Ghidey et al., 1997), which was much less than the 60 days reported in the SCS/ARS/CES Herbicide Properties Database (Wauchope et al., 1992). Atrazine degradation rates in the surface and upper soil layers were calculated to be 0.058 based on the following equation (Donigian et al., 1978):

where:

$$
K D G=0.693 / t_{50}
$$

$\mathrm{KDG}=$ the degradation rate and

$t_{50}=$ the parent herbicide degradation half-life.

Degradation rates in other soil layers were obtained from Donigian et al. (1995). Initial values for $\mathrm{K}_{1}$ and $\mathrm{N}_{1}$ of 2.0 and 1.1 were used (Seybold and Mersie, 1996), but were adjusted to 1.2 and 1.4 for model calibration. The total measured and simulated annual atrazine losses in runoff from 1993 and 1995 were 65.65 
and $62.30 \mathrm{~g} / \mathrm{ha}$, respectively. The total measured and simulated atrazine losses during the critical period from April to June were 63.45 and $60.21 \mathrm{~g} / \mathrm{ha}$, respectively. The comparison of simulated and recorded amounts of atrazine in the critical season and the whole years is good.

\subsection{Summary and Conclusions}

The Goodwater Creek, a gently sloping watershed in the claypan soil region of Missouri, was selected to evaluate the performance of HSPF in simulating runoff, sediment, and pesticides in claypan soils. The watershed demonstrates the typical wetness problems characteristic of claypan soils because of its underlying claypan layer coupled with the nearly level slope. The Goodwater Creek watershed has been used for several hydrological and water quality studies. Previous studies in this watershed provide detailed data for this evaluation.

HSPF was first calibrated on a $36 \mathrm{ha}(89 \mathrm{ac})$ research field within Goodwater Creek watershed. The model was then applied to the entire Goodwater Creek watershed for hydrology verification. The investigation indicated that the HSPF model was successfully calibrated and the model was considered to simulate runoff, sediment, and pesticides in the claypan soil watershed well.

\section{References}

Alberts, E. E., A. T. Hjelmfelt, Jr., W. W. Donald, and N. R. Kitchen. 1995. Herbicide transport in surface runoff from watersheds. Proceedings of the $5^{\text {th }}$ Annual Water Quality Conference, Columbia, MO.

Chew, C. Y., W. M. Lary, and R. H. Smith. 1991. Hydrological simulation of Tennessee's North Reelfoot Creek watershed. Research Journal Water Pollution Control Federation, 63(1) 10-16.

Donigian, A. S., Jr. and H. H. Davis, Jr. 1978. User's Manual for Agricultural Runoff Management (ARM) Model. EPA-600/3-78-080. U.S. Environmental Protection Agency, Athens, GA.

Donigian, A. S., J. C. Imhoff, and B. R. Bicknell. 1983. Modeling water quality and the effects of agricultural best management practices in Four Mile Creek, Iowa. EPA-600/ 3-83-067. U.S. Environmental Protection Agency, Athens, GA.

Donigian, A. S., J. C. Imhoff, B. R. Bicknell, and J. 1. Kittle. 1984. Application Guide for Hydrological Simulation Program - FORTRAN (HSPF). EPA-600/3-84-065. U.S. Environmental Protection Agency, Athens, GA.

Donigian, A. S., Jr., R. V. Chinnaswamy, and R. F. Carsel. 1995. Watershed modeling of agrichemicals in Walnut Creek, IA.:Preliminary assesment of contributions and impacts. In: The International Symposium on Water Quality Modeling, Proceedings of the International Symposium. ASAE, St. Joseph, Michigan, pp 192-201. 
Elliot, W. J. and A. D. Ward. 1995. Soil erosion and control practices. In: Environmental Hydrology, eds. A. D. Ward and W. J. Elliot, 177-203. Boca Raton, FL.

Ghidey, F., E. E. Alberts, and R. N. Lerch. 1997. Spatial and temporal variability of herbicides in a claypan soil watershed. Journal of Environmental Quality. 26: 15551563.

Hjelmfelt, A. T., W. W. Donald, E. E. Alberts, and R. N. Lerch. 1995. Distribution of herbicides in Goodwater Creek, Missouri. Proceedings of the $5^{\text {th }}$ Annual Water Quality Conference, Columbia, MO.

Hjelmfelt, A. T., P. E. Blanchard, W. W. Donald, and E. E. Alberts. 1999. Assessment of Hydrology and Water Quality of Goodwater Creek, Missouri. XXVIII Congress of the International Association for Hydraulic Research (IAHR), Graz, Austria.

Hjelmfelt, A. T. and M. Wang. 1999. Modeling hydrologic and water quality responses to grass waterways. Journal of Hydrologic Engineering, ASCE 4(3) 251-256.

Laroche, A. M., J. Gallichand, R. Lagace, and A. Pesant. 1996. Simulating atrazine transport with HSPF in an agricultural watershed. Journal of Environmental Engineering. ASCE 122(7) 622-630.

Moore, W., H. Matheny, T. Tyree, D. Sabatini, and S. J. Klaine. 1988. Agricultural runoff modeling in a small west Tennessee watershed. Research Journal Water Pollution Control Federation. 60(2) 242-249.

Qiu, Z. 1996. Integrated Assessment of Agricultural Nonpoint Source Pollution in Goodwater Creek Watershed, Missouri. Ph.D. thesis, The University of MissouriColumbia, Columbia, MO.

Seybold, C. A. and W. Mersie. 1996. Organic chemicals in the environment: Adsorption and desorption of atrazine, deethylatrazine, deisopropylatrazine, hydroxyatrazine, and metolachlor in two soils from Virginia. Journal of Environmental Quality 25: 1179-1185.

Srinivasan, M. S., J. M. Hamlett, R. L. Day, J. I. Sams, and G. W. Petersen. 1998. Hydrologic modeling of two glaciated watersheds in northeast Pennsylvania. Journal of the American Water Resources Association, AWRS, 34(4) 963-978.

U.S. Soil Conservation Service. 1981. Agriculture Handbook 296: Land Resource Regions and Major Land Resource Areas of the United States. Washington, D.C.

Wang M. and A. T. Hjelmfelt. 1998. DEM based overland flow routing model. Journal of Hydrologic Engineering, ASCE, 3(1) 1-8.

Wauchope, R. D., T. M. Buttler, A. G. Hornsby, P. W. M. Augustijn-Beckers, and J. P. Burt. 1992. The SCS/ARS/CES pesticide properties database for environmental decision-making. In: Reviews of Environmental Contamination and Toxicology. Vol. 123, Springer-Verlag, New York Inc.164 p. 